\title{
HUBUNGAN PENGETAHUAN DAN PERSEPSI DENGAN STATUS GIZI \\ BALITA DI PUSKESMAS PAAL MERAH I KOTA JAMBI TAHUN 2017
}

\author{
Kristy MellyaPutri \\ email: kristymellyaputri@rocketmail.com
}

\begin{abstract}
According to Susenas in 2005, the prevalence rate of under nutrition is $28 \%$, and among those $8.8 \%$ suffer from malnutrition. It is estimated that there are still unreported (under reported) (Riskesdas, 2011).

This research is quantitative descriptive conducted at Puskesmas Paal Merah I of Jambi City and has been implemented in June 2017. The population of this research is mother who have toddler who visited Puskesmas Paal Merah I Jambi from January to March 2017 as many as 768 people and the number of samples of 41 people with accidental sampling technique. Data collection with questionnaires, univariate and bivariate analyzes.

The results showed that as many as 9 respondents $(22.0 \%)$ had good knowledge, 22 respondents $(53.7 \%)$ had enough knowledge, and 10 respondents $(24,4 \%)$ had bad knowledge. A total of 27 respondents $(65.9 \%)$ had positive perceptions, and as many as 14 respondents $(34.1 \%)$ had a negative perception. A total of 31 respondents $(75,6 \%)$ have good nutrition status of toddler, and as many as 10 respondents $(24,4 \%)$ have less nutrition status. There is no correlation between knowledge with nutritional status of children under five at Puskesmas Paal Merah I.

There is relationship between perception with nutritional status of children under five years old, with OR 43,200 (4,386 - 425,491). The results of this study is expected to provide health information and counseling about the nutritional status of toddlers by using language that is easy to understand and distribute brochures or leaflets and conduct discussions with respondents.
\end{abstract}

Keywords:Knowledge, Perception, Nutrition Status of Toddler AkademiKebidanan Jakarta Mitra Sejahtera.

Sampai saat ini 76,4 juta penduduk Indonesia tergolong miskin dan hampir miskin,serta tinggal didaerah yang sulit dijangkau. Menurut Susenas tahun 2005 angka prevalensi gizi kurang anak balita $28 \%$, dan diantara angka tersebut $8,8 \%$ menderita gizi buruk. Pada tahun 2008 dari hasil Riskesdas angka tersebut berkurang menjadi $13,0 \%$. Walau prevelansi gizi kurang menurun namun anak yang stunting (pendek) masih cukup tinggi 36,8\% yang berarti pernah menderita kekurangan gizi. Sedangkan prevalensi gizi buruk 5,4\%. Keterangan lebih lanjut diperkirakan masih ada yang tidak 
terlaporkan (under reported), wajarlah bila kerap terdapat pemberitaan adanya kasus gizi buruk disana-sini (Riskesdas, 2011).

Anak umur 0-5 tahun merupakan periode penting dalam tumbuh kembang anak, karena masa ini merupakan masa pertumbuhan dasar yang mempengaruhi dan menentukan perkembangan selanjutnya. Tumbuh kembang balita melalui periode atau tahapan tumbuh kembang tertentu yang secara pesat dapat mencapai tumbuh kembang yang optimal (Eveline \& Djamaludin, 2010:1).

Status gizi balita merupakan hal penting yang harus diketahui oleh setiap orang tua. Perlunya perhatian lebih dalam tumbuh kembang di usia balita didasarkan fakta bahwa kurang gizi yang terjadi pada masa emas ini bersifat ireeversible (tidak dapat pulih). Ukuran tubuh yang pendek ini merupakan tanda kurang gizi yang berkepanjangan. Lebih jauh, kekurangan gizi dapat mempengaruhi perkembangan otak anak. Padahal otak tumbuh selama masa balita (Marimbi, 2010:92).

Faktor-faktor yang mempengaruhi status gizi pada anak balita disebabkan oleh beberapa faktor yang kemudian diklasifikasikan sebagai penyebab langsung, penyebab tidak langsung, pokok masalah dan akar masalah. Gizi kurang secara langsung disebabkan oleh kurangnya konsumsi makanan dan adanya penyakit infeksi. Makin bertambah usia maka semakin anak bertambah pula kebutuhannya, konsumsi makanan dalam keluarga dipengaruhi jumlah dan jenis pangan yang dibeli,pemasakan, distribusi dala keluarga dan kebiasaan makan secara perorangan. Konsumsi juga tergantung pada pendapatan,agama,adat istiadat, dan pendidikan keluarga yang bersangkutan (Marmi, 2010:377)
Dalam kehidupan masyarakat seharihari sering terlihat keluarga yang berpenghasilan cukup akan tetapi makanan yang dihidangkan seadanya. Dengan demikian, kejadian gangguan gizi tidak hanya ditemukan pada keluarga yang berpenghasilan kurang akan tetapi juga pada keluarga yang berpenghasilan relatif baik (cukup). Keadaan ini menunjukkan bahwa ketidaktahuan akan makanan bagi kesehatan tubuh mempunyai sebab buruknya mutu gizi makanan pada keluarga (Marimbi, 2010).

Berdasarkan data DinasKesehatan Kota Jambi Tahun 2016/2017 Puskesmas Paal Merah I Kota Jambi merupakan puskesmas yang tertinggi gizi kurang pada balita dan mengalami peningkatan dari setiap tahunnya yaitu pada tahun 2015 balita yang mengalami gizi kurang sebanyak 9 balita $(0,8 \%)$ dan mengalami gizi buruk sebanyak 1 balita $(0,1 \%)$. Sedangkan tahun 2016 balita yang mengalami gizi kurang sebanyak 23 balita $(4,0 \%)$ dan mengalami gizi buruk sebanyak 5 balita $(0,9 \%)$. Tujuan penelitian adalah untuk mengetahui hubungan pengetahuan dan depresi dengan Status Gizi di Puskesmas Paal Merah I Kota Jambi.

\section{METODE PENELITIAN}

Penelitian ini merupakan deskriptif kuantitatif dengan desain cross sectional Penelitian ini dilakukan pada ibu yang memiliki balita berkunjung ke Puskesmas Paal Merah I Kota Jambi dengan populasi sebanyak 786 orang dan sampel sebanyak 41 orang. Teknik pengambilan sampel menggunakan accidental sampling. Penelitian ini meng-gunakan data primer dan data sekunder. Variabel dependen sindrom status gizi balita, sedangkan variabel independen pengetahuan dan persepsi. 
Teknik pengumpulan data dengan pengisian kuesioner. Analisis data yang digunakan dalam penelitian adalah univariat dan bivariat menggunakan chi-square.

\section{HASIL DAN PEMBAHASAN}

Analisis univariat dilakukan untuk mengetahui distribusi frekuensi setiap variabel, baik variabel dependen dan independen.

Tabel 1

Distibusi Responden BerdasarkanUsia di Puskesmas Paal Merah I Kota Jambi Tahun $2017(n=41)$

\begin{tabular}{ccc}
\hline Usia & Jumlah & $\%$ \\
\hline$<20$ tahun & 6 & 14,6 \\
$20-35$ tahun & 28 & 68,3 \\
$>35$ tahun & 7 & 17,1 \\
\hline Total & $\mathbf{4 1}$ & $\mathbf{1 0 0}$ \\
\hline
\end{tabular}

Berdasarkan tabel 1 menunjukkan bahwa dari 41 responden berdasarkan pendidikan di Puskesmas Paal Merah I Kota Jambi, sebagian besar responden berpendidikan SMP sebanyak 24 orang $(58,5 \%)$.

Tabel 2

DistibusiRespondenBerdasarkan Pen-didikan di PuskesmasPaalMerah I Kota Jambi Tahun $2017(n=41)$

\begin{tabular}{ccc}
\hline Pendidikan & Jumlah & \% \\
\hline SD & 11 & 26,8 \\
SMP & 24 & 58,5 \\
SMA & 4 & 9,8 \\
PT & 2 & 4,9 \\
\hline Total & $\mathbf{4 1}$ & $\mathbf{1 0 0}$ \\
\hline
\end{tabular}

Tabel 2 menunjukkan bahwa bahwa dari 41 responden berdasarkan pendidikan di Puskesmas Paal Merah I Kota Jambi, sebagian besar responden berpendidikan SMP sebanyak 24 orang $(58,5 \%)$.

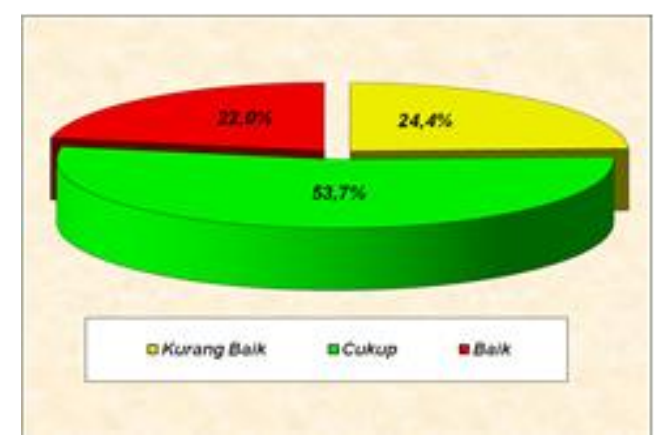

Diagram 1

Distibusi Responden Berdasarkan Pengetahuan Ibu tentang Status Gizi Balita di Puskesmas Paal Merah I Kota Jambi Tahun 2017 (n=41)

Berdasarkan hasil pertanyaan pengetahuan mayoritas responden yaitu sebanyak 34 responden $(82,9 \%)$ tidak mengetahui pengukuran yang biasa dilakukan untuk menilai gizi balita, sebanyak 31 responden $(75,6 \%)$ tidak mengetahui faktor yang mempengaruhi gizi kurang pada balita dan sebanyak 29 responden $(70,7 \%)$ tidak mengetahui pengertian gizi kurang pada balita.Gambaran pengetahuan responden tentang status gizi balita di Puskesmas Paal Merah I Kota Jambi ada 3 kategori yaitu pengetahuan baik, cukup dan kurang baik. Kategori pengetahuan baik diperoleh bila skor jawaban $\geq 76 \%$ total skor atau responden dapat menjawab pertanyaan tentang status gizi balita dengan benar sebanyak 8-10 pertanyaan, dikategorikan pengetahuan cukup bila skor jawaban antara 56-75\% total skor atau menjawab pertanyaan tentang status gizi balita dengan benar 6-7 pertanyaan dan dikategorikan pengetahuan kurang baik bila skor jawaban $<56 \%$ total skor atau menjawab pertanyaan tentang status gizi balita dengan benar $<6$ pertanyaan. Berdasarkan hasil 
analisis data pada diagram 1, diketahui bahwa dari 41 responden yang telah diteliti mengenai pengetahuan tentang status gizi balita di Puskesmas Paal Merah I Kota Jambi, didapat bahwa sebanyak 9 responden $(22,0 \%)$ mempunyai pengetahuan yang baik tentang status gizi balita, sebanyak 22 responden $(53,7 \%)$ mempunyai pengetahuan cukup tentang status gizi balita dan sebanyak 10 responden $(24,4 \%)$ mempunyai pengetahuan kurang baik tentang status gizi balita.

Penelitian yang telah dilakukan sejalan dengan penelitian Ruhana (2014) mengenai gambaran pengetahuan dan persepsi ibu yang memiliki balita tentang status gizi balita di Puskesmas Antapani Kota Bandung, menunjukkan bahwa sebagian besar yaitu $55,6 \%$ ibu memiliki pengetahuan yang cukup tentang status gizi balita. Selain itu, penelitian ini sejalan dengan penelitian Rianah (2014) mengenai gambaran pengetahuan dan sikap ibu tentang status gizi balita di Puskesmas Pakuan Baru Kota Jambi, menunjukkan bahwa sebesar 54,6\% ibu memiliki pengetahuan cukup tentang status gizi balita. Sedangkan penelitian yang dilakukan Sulistywati (2011) mengenai gambaran pengetahuan dan sikap ibu tentang pemantauan status gizi balita di Puskesmas Simpang IV Sipin menunjukkan bahwa sebagian besar 59,7\% ibu memiliki pengetahuan rendah tentang pemantauan status gizi balita.

Pengetahuan merupakan hasil tahu dari tahu, dan ini terjadi setelah orang melakukan pengindraan terhadap suatu objek tertentu. Pengindraan terjadi melalui panca indra manusia, yakni indra penglihatan, pendengaran, penciuman, rasa dan raba. Sebagian besar pengetahuan manusia diperoleh melalui mata dan telinga (Notoatmodjo, 2010).

Dari penjelasan diatas, sebagian besar responden memiliki pengetahuan cukup, hal ini dikarenakan kesadaran dan minat yang masih rendah untuk mencari tambahan informasi untuk meningkatkan pengetahuannya, disamping itu juga dapat dikarenakan sudah pernah diberikan penyuluhan kesehatan oleh responden tersebut mengenai status gizi balita tetapi responden lupa atau tidak ingat dengan informasi yang pernah didapat. Hal ini dapat juga dipengaruhi oleh tingkat pendidikan responden karena sebagian besar responden berpendidikan SD sebanyak 11 responden $(26,8 \%)$ dan SMP sebanyak 24 orang $(58,5 \%)$, sehingga dalam menerima informasi masih belum dapat diterima dengan baik karena tingkat pendidikan hanya dalam tingkat tahu atau tingkat yang paling rendah dan belum dapat memahami apabila untuk mengaplikasikan informasi yang telah diberikan

Upaya-upaya yang perlu dilakukan untuk meningkatkan pengetahuan responden tentang status gizi balita adalah dilakukannya pendidikan kesehatan oleh petugas kesehatan kepada responden mengenai status gizi balita, menjelaskan dengan menggunakan bahasa yang mudah dimengerti agar responden dapat memahami dengan baik dan juga dengan cara memberikan leaflet, brosur, dan kegiatan promotif lainnya seperti melakukan diskusi bersama responden.

Selain itu diharapkan responden untuk aktif mencari informasi tentang status gizi balita agar menambah pengetahuan responden yang kurang baik. Jika hanya pasif saja, maka akan berdampak kurang baik pada tingkat pengetahuan mereka. Bagi responden 
yang telah mempunyai pengetahuan yang baik, harus selalu dipertahankan dan diingat materi-materi yang telah diberikan sebelumnya, agar mereka mengetahui pentingnya status gizi balita.

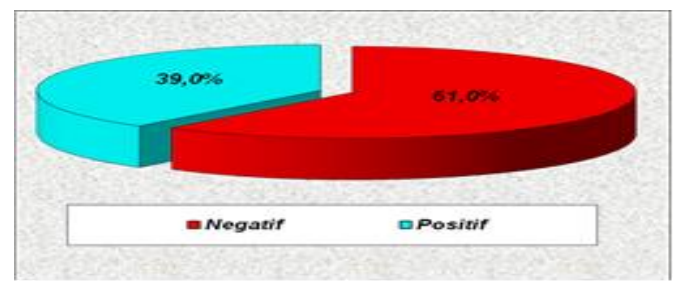

\section{Diagram 2}

Distibusi Responden Berdasarkan Persepsi Ibu tentang Status Gizi Balita di Puskesmas Paal Merah I Kota Jambi Tahun $2017(n=41)$

Berdasarkan hasil pertanyaan persepsi mayoritas sebanyak 8 responden $(19,5 \%)$ menjawab Sangat Setuju pada pernyataan menganggap gizi baik ataupun buruk pada balita tergantung pemberian makanan oleh ibu, sebanyak 32 responden $(78,0 \%)$ menjawab Setuju pada pernyataan menganggap susu formula tidak ada masalah jika diberikan tidak sesuai dengan usia balita, sebanyak 31 responden $(75,6 \%)$ menjawab Tidak Setuju pada pernyataan menganggap keadaan gizi kurang pada mempunyai dampak keterlambatan pertumbuhan dan perkembangan balita, dan sebanyak 6 responden $(14,6 \%)$ menjawab Sangat Tidak Setuju pada pernyataan menganggap memberikan makanan yang bergizi sesuai dengan umur balita.Untuk melihat kategori gambaran persepsi responden tentang status gizi balita di Puskesmas Paal Merah I Kota Jambi ada 2 kategori yaitu persepsi positif dan persepsi negatif. Kategori persepsi positif diperoleh bila skor jawaban $\geq$ mean dan dikategorikan persepsi negatif bila skor jawaban < mean. Nilai mean adalah 26,22. Berdasarkan hasil analisis data pada diagram 2, dapat disimpulkan bahwa dari 41 responden yaitu sebanyak 27 responden $(65,9 \%)$ memiliki persepsi positif tentang status gizi balita, dan sebanyak 14 responden $(34,1 \%)$ memiliki persepsi negatif terhadap status gizi balita.

Sebanyak 32 responden $(78,0 \%)$ menjawab Setuju pada pernyataan menganggap susu formula tidak ada masalah jika diberikan tidak sesuai dengan usia balita. Menurut peneliti, responden memiliki pandangan bahwa susu formula tidak akan menjadi masalah jika diberikan pada balita jika pemberian susu formula diberikan sesuai usia balita tersebut.

Sebanyak 31 responden $(75,6 \%)$ menjawab Tidak Setuju pada pernyataan menganggap keadaan gizi kurang mempunyai dampak keterlambatan pertumbuhan dan perkembangan balita. Perlunya perhatian lebih dalam tumbuh kembang di usia balita didasarkan fakta bahwa kurang gizi yang terjadi pada masa emas ini bersifat ireeversible (tidak dapat pulih). Ukuran tubuh yang pendek ini merupakan tanda kurang gizi yang berkepanjangan. Lebih jauh, kekurangan gizi dapat mempengaruhi perkembangan otak anak. Padahal otak tumbuh selama masa balita.

Sebanyak 6 responden $(14,6 \%)$ menjawab Sangat Tidak Setuju pada pernyataan menganggap memberikan makanan yang bergizi sesuai dengan umur balita. Menurut peneliti, responden sudah memiliki pandangan bahwa untuk memberikan makanan yang bergizi harus melihat usia balita sehingga pada saat memberikan makanan tidak sembarangan. 
Penelitian yang telah dilakukan sejalan dengan penelitian Ruhana (2014) mengenai gambaran pengetahuan dan persepsi ibu yang memiliki balita tentang status gizi balita di Puskesmas Antapani Kota Bandung, menunjukkan bahwa sebagian besar yaitu $81,4 \%$ ibu memiliki persepsi negatif terhadap status gizi balita. Selain itu, penelitian ini sejalan dengan penelitian Fitria (2016) mengenai persepsi dan motivasi ibu terhadap pemantauan status gizi balita di Puskesmas Indragiri Hilir menunjukkan bahwa sebesar 53,9\% ibu memiliki persepsi negatif terhadap pemantauan status gizi balita.

Persepsi merupakan suatu proses yang didahului oleh proses penginderaan, yaitu merupakan proses diterimanya stimulus oleh individu melalui alat indera atau juga disebut proses sensoris. Namun proses itu tidak berhenti begitu saja, melainkan stimulus tersebut diteruskan dan proses selanjutnya merupakan proses persepsi. Karena itu proses persepsi tidak dapat lepas dari proses penginderaan dan proses penginderaan merupakan proses pendahulu dari proses persepsi (Walgito, 2010).

Berdasarkan penjelasan diatas terlihat bahwa sebagian kecil responden mempunyai persepsi negatif terhadap status gizi balita dikarenakan responden tidak memiliki informasi lebih mendalam tentang status gizi balita, sehingga hanya dengan informasi secara umum membentuk suatu pandangan negatif terhadap status gizi balita. Oleh karena itu, upaya-upaya yang perlu dilakukan untuk membentuk persepsi positif terhadap status gizi balita adalah diberikannya penyuluhan mengenai status gizi balita, dengan penyuluhan tersebut memungkinkan responden membuat keputusan yang logis dan matang terhadap status gizi balita.

Upaya selanjutnya yaitu dengan diberikan pendidikan kesehatan berkaitan dengan persepsi yang baik dan tidak baik tentang status gizi balita dengan cara memberikan informasi dan menanamkan nilai-nilai serta persepsi positif. Hal ini dapat dilakukan dengan memberikan leaflet dan informasi seperti spanduk dalam upaya memberikan pengetahuan secara luas agar terbentuk persepsi yang positif. Selain itu mengajak responden melakukan diskusi bersama dalam membahas permasalahan status gizi balita agar responden tidak lagi bingung dan membentuk anggapan positif.

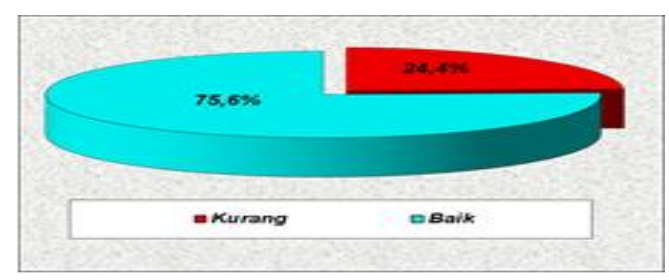

\section{Diagram 3}

Distibusi Responden Berdasarkan Status Gizi Balita di Puskesmas Paal Merah I Kota Jambi Tahun 2017 ( $\mathrm{n}=41)$

Gambaran status gizi balita di Puskesmas Paal Merah I Kota Jambi diperoleh melalui KMS/Tabel NCHS. Berdasarkan hasil analisis data, dapat disimpulkan bahwa dari 41 responden yaitu sebanyak 31 responden $(75,6 \%)$ memiliki status gizi balita baik, dan sebanyak 10 responden $(24,4 \%)$ memiliki status gizi balita kurang.

Berdasarkan hasil penelitian, responden yang memiliki pengetahuan yang cukup dan memiliki persepsi positif tidak sebanding dengan status gizi yang dialami oleh balita tersebut. Hal ini disebabkan oleh berbagai faktor misalnya dari segi pengetahuan 
sebagian besar ibu menganggap bahwa makanan cepat saji baik untuk anaknya padahal, makanan tersebut memiliki gizi yang rendah.

\section{Tabel 3}

Analisa Hubungan Pengetahuan dengan Status Gizi Balita di Puskesmas Paal Merah I Tahun $2017(n=41)$

\begin{tabular}{clllll}
\hline & \multicolumn{4}{c}{ Status Gizi } & P \\
\cline { 2 - 5 } Pengetahuan & \multicolumn{3}{c}{ Kurang } & \multicolumn{3}{c}{ Baik } & value \\
\cline { 2 - 5 } & $\mathrm{f}$ & $\%$ & $\mathrm{f}$ & $\%$ & \\
Kurang baik & 3 & 30 & 7 & 70 & 0.606 \\
Cukup & 5 & 22,7 & 17 & 77,3 & \\
Baik & 1 & 11,1 & 8 & 88,9 & \\
\hline Total & 9 & 22 & 32 & 78 & \\
\hline
\end{tabular}

Berdasarkan hasil penelitian, responden yang memiliki pengetahuan yang baik dan memiliki persepsi negative tidak sebanding dengan status gizi yang dialami oleh balita tersebut. Hal ini disebabkan oleh berbagai faktor misalnya dari segi persepsi sebagian ibu masih mempercayai adat istiadat setempat misalnya ibu masih mempercayai tentang pantangan maka-nan yang tidak boleh dikonsumsi padahal makanan tersebut baik buat anaknya sehingga asupan gizi anaknya tidak terpenuhi.

Hasil didapatkan 41 responden dengan pengetahuan kurang baik mengalami status gizi kurang 30\%. Sedangkan dari 22 reponden dengan pengetahuan cukup didapat $22,7 \%$ yang status gizi kurang. Dari hasil uji statistik chi-square diperoleh nilai p_value 0,606 $(\mathrm{p}<0,05)$ dengan demikian dapat disimpulkan bahwa tidak ada hubungan antara pengetahuan dengan status gizi balita di Puskesmas Paal Merah I. Penelitian ini tidak sejalan dengan penelitian Fikri (2016) adanya hubungan pengetahuan ibu dengan status gizi balita dengan $\mathrm{p}$ value $(0,001)$.
Menurut Notoatmodjo (2010) factor-faktor yang mempengaruhi pengetahuan yaitu pendidikan, media atau informasi, social budaya, ekonomi, lingkungan, usia. Didapatkan bahwa pendidikan ibu sebagian besar yaitu SMP danusiaibusebagianbesar 20-35 tahun. Pendidikan adalah suatu usaha untuk mengembangkan kepribadian dan kemampuan di dalam dan luar sekolah ber-langsung seumur hidup dan usia mempengaruhi daya tangkap dan pola pikir seseorang. Semakin bertambah usia akan makin bertambah pula daya tangkap dan pola pikirnya, sehingga pengetahuan yang diperolehnya semakin membaik.

\section{Tabel 4}

Analisa Hubungan Persepsi dengan Status Gizi Balita di Puskesmas Paal Merah I Tahun $2017(n=41)$

\begin{tabular}{lccccc}
\hline & \multicolumn{4}{c}{ Status Gizi } & P \\
\cline { 2 - 5 } Persepsi & \multicolumn{2}{c}{ Kurang } & \multicolumn{2}{c}{ Baik } & value \\
\cline { 2 - 5 } & $\mathrm{f}$ & $\%$ & $\mathrm{f}$ & $\%$ & 0,000 \\
Negatif & 8 & 61,5 & 5 & 38,5 & \\
Positif & 1 & 3,6 & 27 & 96,4 & \\
\hline Total & 9 & 22 & 32 & 78 & \\
\hline
\end{tabular}

Hasil didapatkan dari 13 responden persepsinegatif yang status gizibaik sebanyak $38,5 \%$, didapat dari 28 responden persepsi positif yang status gizi kurang sebanyak 3,6\%. Dari hasil uji statistik chi-square diperoleh nilai p_value 0,000 ( $\mathrm{p}<0,05)$ dengan demikian dapat disimpulkan bahwa ada hubungan antara persepsi dengan status gizi balita, dengan nilai OR 43.200 (4.386 - 425.491), ini berarti bahwa responden dengan persepsi negative mempunyai peluang sebesar 43 - 44 kali mengalami status gizi kurang dibandingkan dengan responden persepsi positif. Penelitian ini sejalan dengan penelitian Dewi 
(2010) adanya hubungan persepsi ibu dengan status gizi balita dengan $\mathrm{p}$ value $(0,031)$.

Ada banyak faktor yang menyebabkan stimulus dapat masuk dalam rentang perhatian. Faktor penyebab ini dapat dibagi menjadi dua bagian besar yaitu eksternal dan internal. Faktor eksternal meliputi kontras (kontras warna, ukuran, bentuk dan gerakan), perubahan intensitas, pengulangan sesuatu yang baru dan menjadi perhatian orang banyak. Faktor internal (pengetahuan/pengalaman, harapan, kebutuhan, motivasi, emosi dan budaya) (Notoatmodjo, 2010)

\section{KESIMPULAN DAN SARAN}

Hasil penelitian menunjukkan bahwa sebanyak 9 responden $(22,0 \%)$ mempunyai pengetahuan yang baik, sebanyak 22 responden $(53,7 \%)$ mempunyai pengetahuan cukup, dan sebanyak 10 responden $(24,4 \%)$ mempunyai pengetahuan kurang baik. Sebanyak 27 responden $(65,9 \%)$ memiliki persepsi positif, dan sebanyak 14 responden $(34,1 \%)$ memiliki persepsi negatif. Sebanyak 31 responden $(75,6 \%)$ memiliki status gizi balita baik, dan sebanyak 10 responden $(24,4 \%)$ memiliki status gizi balita kurang. Tidak ada hubungan antara pengetahuan dengan status gizi balita di Puskesmas PaalMerah I. Ada hubungan antara persepsi dengan status gizi balita, dengan nilai OR $43.200 \quad$ (4.386425.491).

Hasil penelitian ini diharapkan pihak puskesmas memberikan informasi dan penyuluhan tentang status gizi balita dengan menggunakan bahasa yang mudah dimengerti dan membagikan brosur atau leaflet serta melakukan diskusi bersama responden.

\section{DAFTAR PUSTAKA}

Andarwati, Dewi, 2007. Faktor-Faktor Yang Berhubungan Dengan Status Gizi Balita Pada Keluarga Petani di Desa Purwojati Kec. Kertek Kabupaten Wonosobo. Fakultas Ilmu Keolahragaan Jurusan Ilmu Kesehatn Masyarakat. Universitas Negeri Semarang.

Arikunto, Suharsimi, 2010. Prosedur Penelitian Suatu Pendekatan Praktik, Penerbit PT Rineka Cipta. Jakarta.

Departemen Gizi Dan Kesehatan Masyarakat, 2010. Gizi Dan Kesehatan Masyarakat. Penerbit PT Raja Grafindo Persada. Jakarta.

Dewi, C. I, 2010. Hubungan Pengetahuan, Sikap dan Persepsi Ibu dengan Pemenuhan Kecukupan Gizi Balita. Tesis: Universitas Sebelas Maret Surakarta

Eveline \& Nanang Djamaludin, 2010. Panduan Pintar Merawat Bayi Dan Balita. Penerbit PT Wahyu Media. Jakarta.

Fikri, Jahidul, 2016. Hubungan Pengetahuan Ibu tentang Gizi Balita dengan Status Gizi Balita di DesaCitereup Kec. Dayeuhkolot Kabupaten Bandung. Skripsi : Stikes Dharma Husada.

Fitria,2016. Persepsi Dan Motivasi Ibu Terhadap Pemantauan Status Gizi Balita Di Puskesmas Indragiri Hilir.

Hayati, Aslis Wirda, 2009. Buku Saku Gizi Bayi. Penerbit Buku Kedokteran EGC. Jakarta. 
Hidayat, Aziz Alimul, 2010. Metode Penelitian Kesehatan Paradigma Kuantitaif. Penerbit Health Books Publishing. Surabaya.

Notoadmodjo, Soekidjo. 2010. "Promosi Kesehatan Teori Dan Aplikasi". Jakarta : Rineka Cipta.

.2010. Ilmu Perilaku Kesehatan.PT. Rineka Cipta. Jakarta.

2010. Metodologi Penelitian Kesehatan. PT. Rineka Cipta. Jakarta.

Marimbi, Hanum, 2010. Tumbuh Kembag, Status Gizi, dan Imunisasi Dasar Pada Balita. Penerbit Nuha Medika. Yogyakarta.

Marmi \& Rahardjo, Kukuh, 2012. Asuhan Neonatus, Bayi, Balita, dan Anak Prasekolah. Penerbit. Pustaka Pelajar. Yogyakarta

Purwaningsih, 2012. Pengertian dan Alat Ukur Pemantauan Status Gizi. Dalam http:// www. Indonesian-publichealth. Com 12013 /03/pemantauan-statusgizi.html. (Diakses tanggal 10 April 2017).

Proverawati, Atikah, 2009. Buku Ajar Gizi Untuk Kebidanan. Penerbit Nuha Medika. Yogyakarta.

Ruhana, Maria. 2014. Gambaran Pengetahuan Dan Persepsi Ibu Yang Memiliki Balita Tentang Status Gizi Balita Di Puskesmas Antapani Kota Bandung.

Saryono, 2011. Metodologi Penelitian Kesehatan Penuntun Praktis
Bagi Pemula. Penerbit Mitra Cendikia. Yogyakarta

Septiari, Bety Bea, 2012. MencetakBayiCerdasdanPolaAs uhOrang Tua.PenerbitNuhaMedika. Yogyakarta Simangunsong, Matthew Mindo P, 2009. Status Gizi. FK Univesitas Indonesia.

Suhardjo, 2010. Pemberian Makanan Pada Bayi dan Anak. Penerbit Kanisius. Yogyakarta.

Sulistyaningsih, 2011. Metodologi Penelitian Kebidanan KuantitatifKualitatif. Penerbit Graha Ilmu. Yogyakarta.

Sulistywati,2011. Gambaran Pengetahuan Dan Sikap Ibu Tentang Pemantauan Status Gizi Balita Di Puskesmas Simpang IV Sipin.

Walgito, Bimo, 2010. Pengantar Psikologi Umum. Penerbit CV. Andi. Yogyakarta.

Wawan, A dan Dewi, 2011. Teori dan Pengukuran Pengetahuan, Sikap, dan Perilaku Manusia. Penerbit Nuha Medika. Yogyakarta. 